\title{
First building engineers in architectural practice of St. Petersburg at the beginning of the 19th century
}

\author{
Ekaterina Vozniak $^{1,{ }^{*}}$, Svetlana Golovina ${ }^{1}$, and Maria Kolesova $^{1}$ \\ ${ }^{1}$ St. Petersburg State University of Architecture and Civil Engineering, St. Petersburg, Russia
}

\begin{abstract}
The emergence of the specialty of civil engineer in the first half of the 19th century had a significant impact on architectural practice in St. Petersburg. The differentiation of the professions of engineer and architect took place for the first time; both specialists began to participate in the design. The appearance of such engineers as Augustine Betancourt, Matvey Clark, Pierre-Dominique Bazin and Wilhelm von Tretter brought about changes in all areas of architecture and construction. New building structures and materials appeared, as well as methods for checking and calculating. Designing has become comprehensive, the activities of the Committee for Structures and Hydraulic Works led by Betancourt covered urban development, individual buildings and all types of utilities. The formation of engineering education took place, which brought up the next generation of Russian engineers. The article considers the most important aspects of the activities of Augustine Betancourt, who laid the foundations for engineering education in Russia; Matvey Clark, who created the first metal beams and trusses; Pierre Dominique Bazin, who continued the development of engineering education, as well as Wilhelm von Tretter, one of the founders of iron bridge construction in Russia.
\end{abstract}

\section{Introduction}

In the first half of the 19th century, a radical change occurred in the construction and design business due to the emergence of a new specialty - a construction engineer. The first construction engineers in St. Petersburg were foreign specialists who came from Spain, France, Scotland, and Germany. Their activity at the beginning of the 19th century was multifaceted. They developed new unique designs: large-span trusses for building coatings, original dome structures, iron bridges, etc. They were engaged in the creation of a new construction base: the construction of factories for production of building materials and structures. They developed building machines and mechanisms. Finally, they brought up a whole generation of young Russian engineers and changed the approach to the organization of construction in general. The activities of these first civil engineers are not well understood.

\footnotetext{
* Corresponding author: vozniak65@mail.ru
} 
Significant changes took place in all areas of the life of the Russian Empire during the first half of the XIX century, a cardinal change in architecture occurred, the classicism style was replaced by eclecticism. The pace of urbanization was high, trade was actively developing, land and waterway networks were expanding, and the first railways appeared. The industrial revolution, however, in connection with the unresolved peasant question came much later than in some European countries - only in the middle of the century. The changes affected the scope of application of new building materials, the development of new structural solutions, the very practice of organizing the design of buildings. During this period, innovations were of a single character, they were developed and applied to specific buildings usually in capital cities, but the number of such solutions increased over time.

By the beginning of the 19th century, the architect designed the designs, and the design was almost an empirical process, based on the experience of the architect, the simplest calculations and recommendations of past generations of architects. Cases of engineering innovations proposed by the architect are very rare. The most famous cases of engineering innovation, oddly enough, are associated with the names of self-taught architects - A.N. Voronikhin, who built the first dome based on metal structures in the Kazan Cathedral, and N. A. Lvov, who developed the method of earth structure]. At the beginning of the XIX century there was a need for new specialists - engineers, who at that time were few in Russia. The first engineers, with their main activity, considered hydraulic structures, land and waterways, but their innovative ideas, which they developed and applied, gradually changed the architectural and construction practice as a whole.

\section{Materials and methods}

The leading engineers of the beginning of the XIX century were Augustine Betancourt, Matvey Egorovich Clark, Pierre-Dominic Bazin, Wilhelm Tretter. Among other specialists working at that time were Franz Devolant, A. I. Mayorov, S. I. Senover, I. S. Rezimon, R. Baus, G. Lame, B. Clapeyron and many others. However, it was Betancourt, Clark, Bazin and Tretter who laid the foundation of the Russian engineering school and had the most significant influence on architectural practice in the Russian Empire in the first half of the 19 th century.

The activities of the first civil engineers were not sufficiently studied and evaluated. Although a lot of architectural and art history works were devoted to the work of architects of the beginning of the 19th century, the activities of the first engineers who worked directly with K. Rossi, V.S. Stasov and O. Monferan are studied much less. Meanwhile, civil engineers own many of the most important decisions that ensured the very existence of significant architectural structures at the beginning of the 19th century. Currently, there are only a few scientific papers devoted to the first engineers of Russia. The life and works of A. Betancourt are described in the works of D.I. Kuznetsov and A. N. Bogolyubov, articles by L. I. Korenev. An article by P. B. Krivskaya is dedicated to the work of M. Clark as the first director of the St. Petersburg Alexander Foundry. Certain aspects of the activity are considered in the works of T.A. Slavina, A.L. Punina, M.Z. Taranovskaya and other researchers of the architecture of the XIX century.

The material for this article was written on the basis of the analysis of bibliographic and archival data, the study of preserved drawings and documents of architectural monuments of that era. Analysis of the extensive material collected allows us to draw conclusions about the direction and importance of the activities of the first civil engineers in Russia. 


\section{Results and discussion}

Augustine de Betancourt and Molina (1758-1824) was a representative of an aristocratic Spanish family. He was born on the island of Tenerife in the Canary Islands, educated in Paris at the National School of Bridges and Roads, the oldest civil engineering school in the world. A. Betacour's education, as well as experience in engineering in Spain, France and the UK, allowed him to found the first Spanish higher education institution in Spain in 1802, the Corps of Engineers of the Spanish military, and other important assignments. Betancourt led it until 1807, when he moved to Paris and was admitted to the French Academy of Sciences. However, in 1808 he was invited to serve in Russia.

A. Betancour's engineering and construction activities were multifaceted; he designed the first wooden arch bridge in Russia, built the building of the Moscow Exercirhouse with unique large-span farms, and also took part in the design of a cathedral of unprecedented proportions.

The Kamennoostrovsky bridge connecting the Aptekarsky and Kamenny islands on Malaya Nevka was built in 1813 according to the project of Betancourt with the participation of the master stonemason Samson Sukhanov and engineers A. Gotman and S. Panteleev. This bridge became the first permanent bridge in St. Petersburg, earlier bridges on the Neva were temporary floating. The bridge consisted of seven spans blocked by wooden arched trusses. The river abutments of the bridge were welded on a pile foundation, and the coastal abutments were lined with pink granite. It served for 50 years and was the only bridge to survive the flood of 1824 . Betankurovsky bridge, as it was then called, was an achievement of the engineering thought of its time and became a model for such bridges.

In 1817, Betancourt was entrusted with the construction of the Exercirgauz (Manege) in Moscow. To cover the span of 44.86 meters, he used a unique and new for that time cover structure - a wooden rafter truss, which blocked the entire building without intermediate supports. The use of this design gave impetus to the development of roof trusses, not only wooden, but also metal, which. began to be used more and more often during the XIX century.

In 1816, Alexander I commissioned Augustine Augustinovich to find an architect for the restructuring of St. Isaac's Cathedral and Auguste Montferrand became that architect. In 1818 the emperor approved the fifth draft, and the construction of the cathedral began. Betancourt made a great contribution to the design and construction of the temple, it was he who proposed a solid foundation on piles, which allowed to ensure the strength of the building while maintaining part of the old foundation and masonry, preserved from the previous versions of the cathedral (Figure 1). 


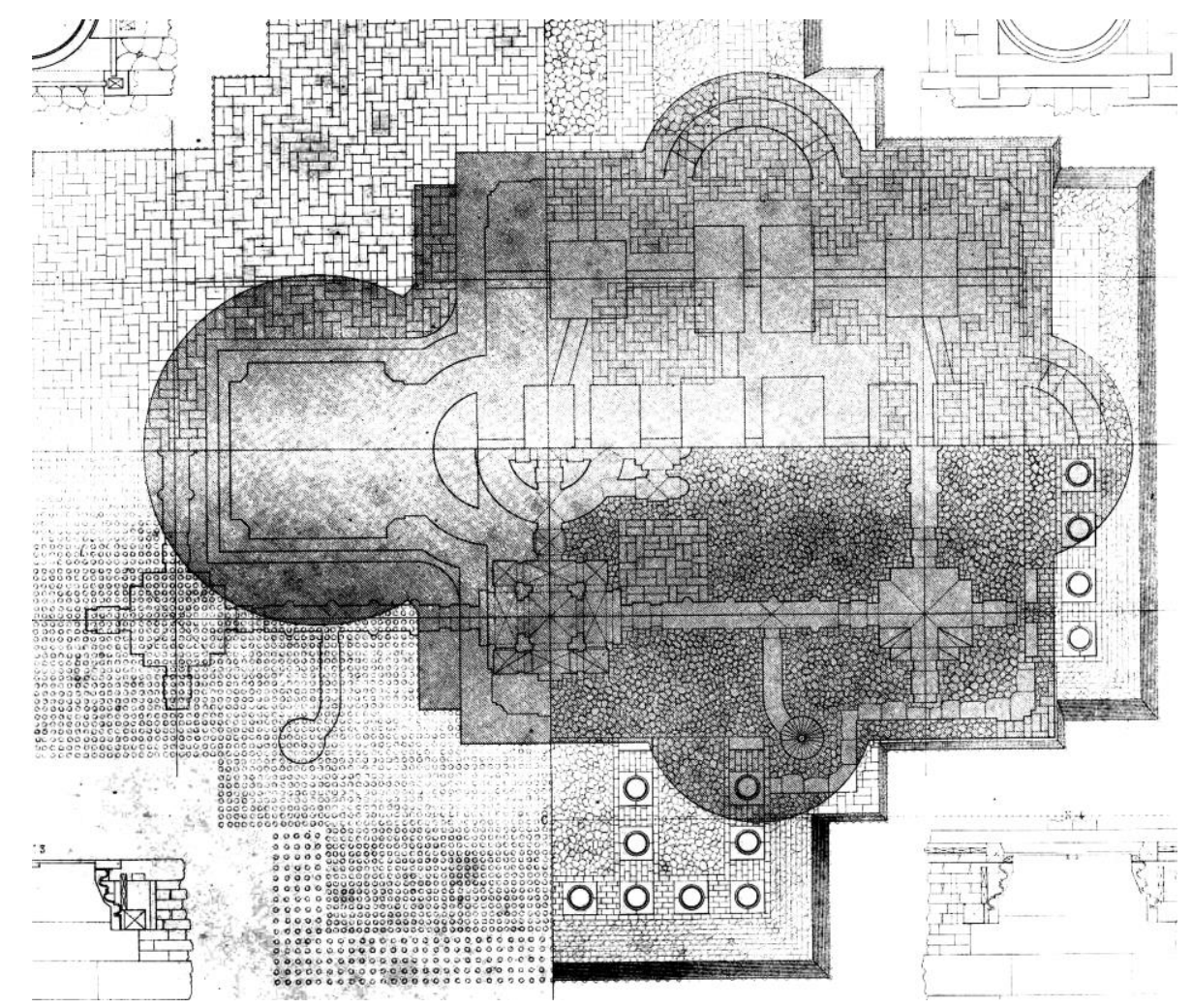

Fig. 1. Pile field and foundations of St. Isaac's Cathedral. A fragment of a drawing of a lithograph from O. Montferrand's album "Eglise cathedrale de St. Isaac" 1845.

A. Betancourt developed scaffolding structures and mechanisms for lifting columns of St. Isaac's Cathedral. Subsequently, O. Monferan lifted the Alexander Column using such mechanisms.

According to the Betancourt project, the Institute of the Corps of Railway Engineers was opened in St. Petersburg on November 1, 1810. The educational system of the institute included fundamental, general engineering and special training. When drawing up the training program at the Institute, A. Betancourt wrote: "The goal of the institute is to provide Russia with engineers who, right after leaving it, could be appointed to carry out all kinds of work in the Empire".

Training at the Institute was based on real building practice. For example, students were directly involved in the design and construction of St. Isaac's Cathedral. "They sketched certain moments of this amazing, long-built object, and Montferrand himself presented his sketches and drawings of the temple. By the way, more than 1000 sheets of these and other works of the famous architect are now stored in the scientific and technical library".

In the process of working at St. Isaac's Cathedral, B. Clapeyron and G. Lame, young engineers, associates of A. Betancourt, developed the theory of domed arches. They published theoretical conclusions in the work "On the stability of arches" and began to read optionally this course at the Institute of the Corps of Railway Engineers.

Betancourt led the Committee for Structures and Hydraulic Works for 8 years since its founding in 1816. Before his death in 1824 , he made a significant contribution to the appearance of the city that we know now. He worked with leading architects of the period in question, namely, K.I. Rossi, V.P. Stasov, O. Montferrand, as well as then-beginning architects A.P. Bryullov, A.I. Shtakenschneider, K.A. Ton. During the work of Betancourt 
as chairman of the committee, Petersburg was transformed. An integrated approach included the construction of ensembles of the main squares of the city (Palace, Senate and Manezhnaya squares, the ensemble of the Mikhailovsky Palace), reconstruction of Nevsky Prospekt, and the solution of issues related to the construction of utilities.

M.E. Clark (1776 - 1846), was an outstanding engineer and organizer, devoted his activities to the development of metal structures in Russia. Matthew Clark (Matvey Egorovich) was born in Scotland, at the age of ten he came from the UK to Russia with his father, George Clark, an associate of Charles Gascoigne, a specialist in the production of guns. In 1792, Clark joined the Kronstadt plant as a model and foundry master, later proved to be an outstanding engineer and expert in iron foundry. Since 1811, M. Clark was appointed superintendent of the St. Petersburg Foundry (Putilovsky), was engaged in the manufacture of the first metal building structures and architectural elements, products for the military department, and also created the first steam engines and unique technical innovations.

The St. Petersburg Foundry was badly damaged by the flood in 1824, and a decision was made to transfer it to the 7th verst of the Shlisselburg tract. In the construction of the new Alexander Foundry, Matvey Egorovich Clark was directly involved and was appointed its director on December 14, 1826. He remained in this position until 1842. Clark took part in the design and supervised the manufacture and installation of most of the products manufactured by the foundry, and the range of products for that time was very wide.

Matvey Clark made a significant contribution to the development of building structures. He, together with architects K.I. Rossi and V.P. Stasov, led the technical office of the plant, which first developed and introduced metal structures in the construction of palaces and public buildings. The construction of ceilings over the auditorium, stage and the entire building of the Alexandrinsky Theater was made of metal according to the project of the architect Rossi and engineer Clark at the Alexandrovsky Iron Foundry for the first time in the world. Innovative designs provoked resistance from other engineers who doubted the reality of implementing such a bold plan, and they demanded a model from Russia to test the structural strength, which was carried out by a special commission of the then most famous engineers L. Carbonier, P. Bazin, K. Opperman, with M. Clark. This was followed by another test of structures directly at the Alexandrovsky Iron Foundry by a commission composed of engineers L. Carbonier, P.-D. Bazin, Wilson, and architects A.E. Staubert and O. Montferrand. The structures were eventually recognized as rational and reliable, withstood all tests and were fully mounted by the summer of 1831 .

The metal structures proposed by C. Rossi and M. Clark were innovative and were used for the first time in the history of construction equipment. The coating consists of 27 iron arch trusses with cast-iron elements, the span of which is $29.8 \mathrm{~m}$. The 18 lower arc-shaped trusses, which have an attic floor and a ceiling above the auditorium, are supported by internal longitudinal walls., Cast-iron brackets are used to support the boxes (Figure 2). 


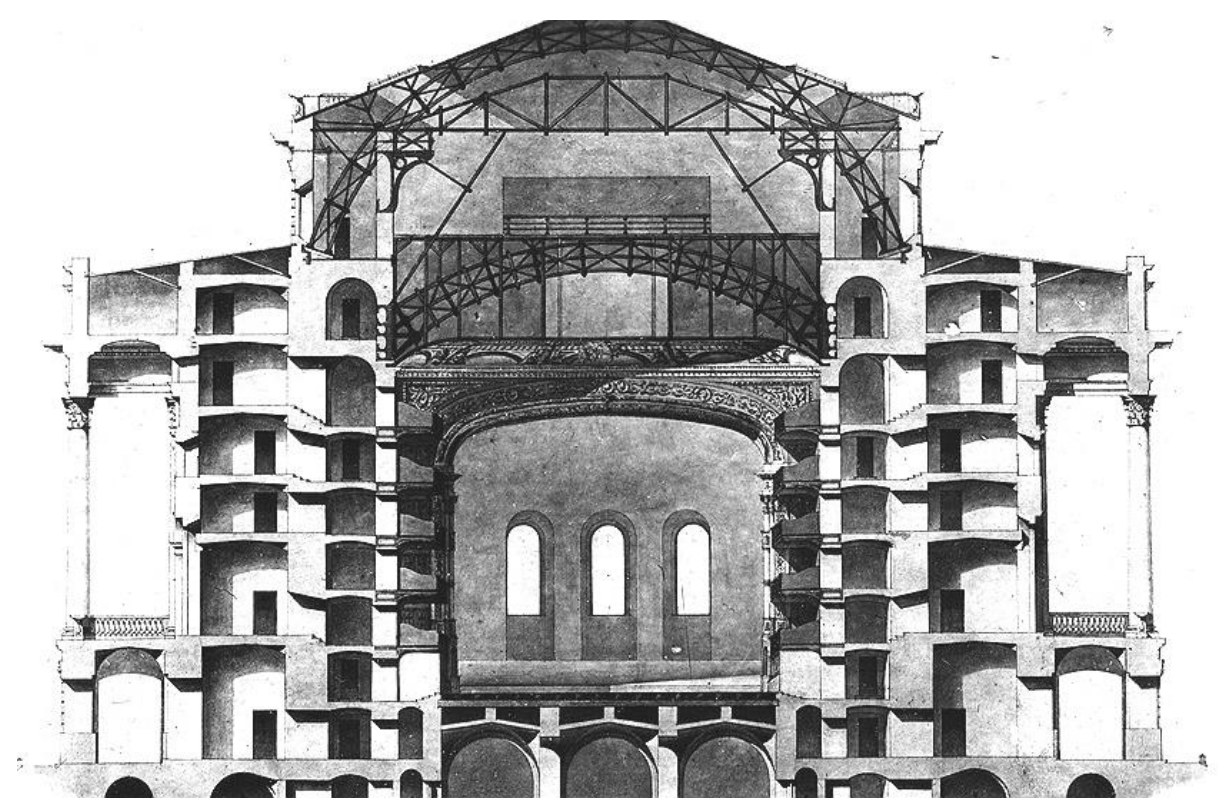

Fig. 2. Cross section of the Alexandria Theater. 19th century drawing.

During the restoration of the Winter Palace after the fire of 1837, Clark developed the first metal "blown" elliptical beams, as well as metal trusses and trusses to cover large spans. Inflated elliptical beams "consist of a system of sheets in two rows folded and placed vertically, which are strengthened laterally by two more systems of sheets that make up the circle to prevent deflection to the sides, so that both of these arched sheets in the cross section of the beam represent the shape of an ellipse". Blown elliptical beams were also used in the construction of the New Hermitage (late 40s - early 50s) and the reconstruction of the Small Hermitage. To fill the girder space, lightweight pottery vaults were first used.

Matvey Clark participated in the creation of the triumphal gates to "My Beloved Companions" and Egyptian in Tsarskoye Selo, Moscow and Narva, decorations for the arch of the General Staff Building, the construction of the Transfiguration and Trinity Cathedrals, the construction and reconstruction of cast-iron bridges (1st Engineering, People's, Little Stables, Theater, Singing). In 1841, Clark designed the first steel bridge of a beam structure in St. Petersburg - the Nikolsky Bridge over the Catherine Canal.

Throughout his career, Clark has been a member of many technical commissions, constantly working with the most respected specialists of his time - engineers, architects, sculptors. Matvey Egorovich also made a significant contribution to the establishment of the Technological Institute, becoming a member of its Training Committee. For several years he headed the technical workshops of the Technological Institute.

Pierre-Dominique Bazin (1810 - 1836) was lieutenant general, professor and secondrector of the Institute of Railway Engineers, a prominent scientist, engineer and mechanic. He was born in France, educated at the Paris Polytechnic School and the School of bridges and roads. Bazin had a direct influence on the formation of engineering education in Russia, he was the second rector of the Institute of the Corps of Railway Engineers.

The most important works of Bazin in St. Petersburg were the deepening of the mouths of the Neva River and its canals, the reorganization of the Okhta powder factory, the construction of the Senate and Synod buildings, and the reconstruction of the University building. He designed the head part of the Obvodny Canal near the Alexander Nevsky 
Lavra, and according to his design, the first chain bridge in Russia was built in Yekaterinhof Park.

P.-D. Bazin owned a project to rebuild the central dome of the Trinity-Izmailovsky Cathedral. The design of the cathedral was carried out by V.P. Stasov. However, the central metal dome designed by Stasov collapsed three years later during the storm, the commission concluded that the structure was too heavy, and the strip of iron edges that made up the dome were not rigid enough. The design of the new dome was entrusted to Bazen, who proposed a classic design of wooden radial trusses.

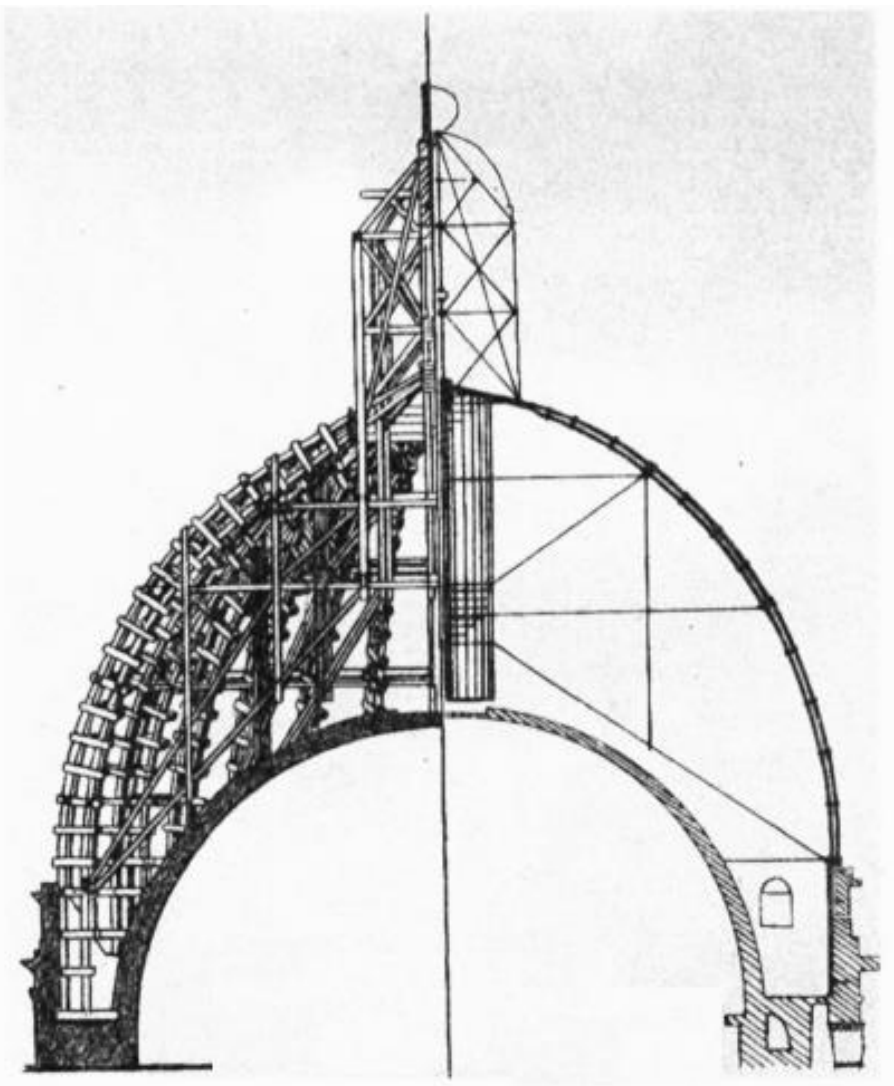

Fig. 3. Sectional view of the dome of the Trinity Izmailovsky Cathedral.

Wilhelm von Tretter (1788-1859) was German engineer, one of the founders of iron bridge construction in Russia. He was also one of the first to use engineering methods for calculating the strength of building structures in practice. Wilhelm von Tretter was born in Germany and came to Petersburg in 1814, worked under the supervision of Betancourt in the Committee for Structures and Hydraulic Works. In the 1820s, Tretter became one of the leading experts in the field of bridge construction. In a report to the managing department of the railways, he proposed the construction of chain suspension bridges in St. Petersburg, similar to those that were widely used in England and America. The Tretter program was highly approved, and in accordance with it, five chain suspension bridges were built in St. Petersburg: Panteleimonovsky and Egyptian through the Fontanka, Pochtamtsky through the Moika, Bankovsky and Lion Bridge through the Catherine's canal. During the construction of the Panteleimon bridge, structural strength tests were carried out, which was the beginning of the application of such tests in construction, the formation of a new science - the resistance of materials. 

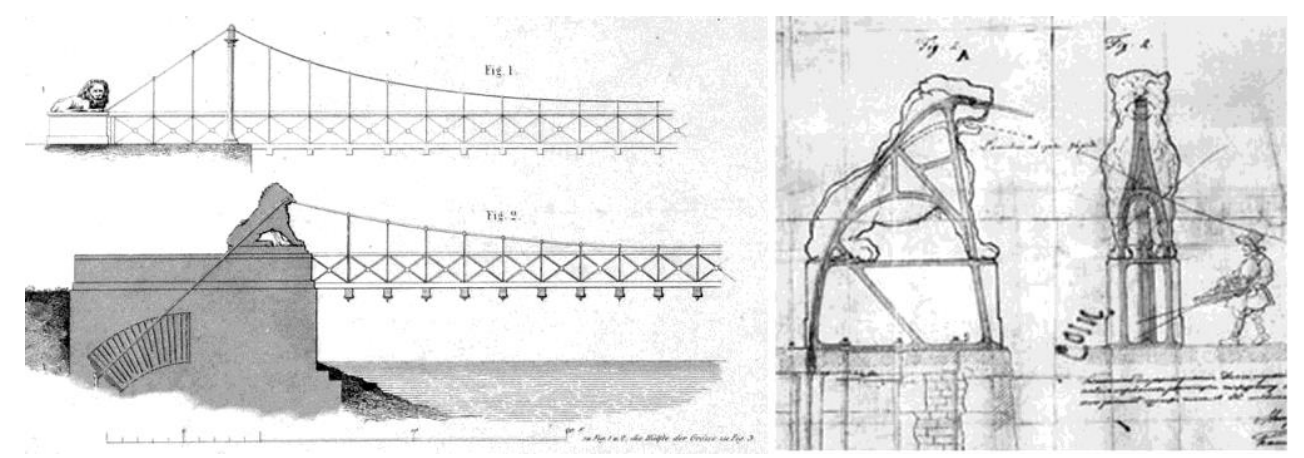

Fig. 4. The Lion Bridge in St. Petersburg. Drawings of the XIX century.

\section{Conclusions}

In the first half of the 19th century, a new specialty was gradually formed in architectural and construction practice in Russia - a construction engineer. The leading engineers at the beginning of the 19th century in St. Petersburg were Augustine Betancourt, Matvey Egorovich Clark, Pierre-Dominic Bazin, Wilhelm Tretter. The first civil engineers contributed:

- creation of such unique structures as St. Isaac's and Trinity Izmailovsky Cathedrals, the Alexandrinsky Theater and other public buildings of St. Petersburg, numerous bridges across the Neva and its tributaries;

- establishment of an engineering education in Russia and creation of the Institute of the Corps of Railway Engineers, emergence of a new generation of Russian engineers;

- emergence of the Committee for Structures and Hydraulic Works with its integrated approach combining significant urban transformations, architecture with all types of utilities;

- development of new building structures and materials, introduction of metal in building structures, development of large-span structures (trusses, domes);

- creation of methods for the experimental verification of the operability of structures, bearing capacity of materials, creation of the first systems for calculating building structures.

Each of the engineers considered in the article contributed to the development of engineering in Russia in the first half of the 19th century, and their interaction with leading architects made it possible to discover new potentialities of structures and materials for realization of previously unprecedented architectural designs. These masters own innovative ideas that forever changed the architectural practice and appearance of St. Petersburg.

\section{References}

1. V.I. Pilyavsky, T.A. Slavina, A.A. Tits, et al., History of Russian architecture: $a$ textbook for high schools (Under the general ed. Yu.S. Ushakova, T.A. Slavina, 2nd ed., p. 600, Stroyizdat, St. Petetsburg, 1994)

2. D.I. Kuznetsov A.A. Betancourt, Veche, 480 (2013)

3. A.A. Betancourt, Water transport, № 7, 6 (2012) 
4. L.I. Korenev, A.A. Betancourt, Russia Bulletin of the St. Petersburg University of Railways (2008) http://korenev.org/index.php/ru/2011-04-07-13-55-37/o-betankure/602011-04-21-20-29 -02

5. P.B. Krivskaya, M. E. Clark, Petersburg Readings, 97, 542-544, St. Petersburg (1997)

6. M.Z. Taranovskay, C. Rossi, Architect. Urban planner. Artist (148-149, Stroyizdat, 1980)

7. S.A. Matsenkov, Attic of the Hermitage (p. 112, The State Hermitage Museum, St. Petersburg, 2011)

8. A.L. Punin, Architecture of St. Petersburg mid-XIX century (2, 600, Kriga, St. Petersburg, 2019)

9. A.L. Punin, The architecture of domestic bridges (p.100, Lenizdat, 1982)

10. L.P. Lavrov, A.F. Krasnopolsky, E.G. Molotkova, Bulletin of Civil Engineers, 4 (63), 26-36, St. Petersburg State University of Architecture and Civil Engineering (2017)

11. K.A. Severin, E.N. Timasheva, Youth Science in the Development of Regions, 1, 329332, Perm National Research Polytechnic University (2018)

12. R.A. Mangushev, N.S. Novokhodskaya, T.A. Datsyuk, L.N. Kondratyev, Bulletin of Civil Engineers, № 5 (76), 33-40 (2019)

13. L.N. Kondratyev, S.V. Sementsov, Yu.V. Pukharenko, Bulletin of Civil Engineers, № 6 (59), 53-59 (2016) 